\title{
Method for estimating the wind power micro and minigeneration applied to a city with a subtropical climate in south America
}

\author{
Método para estimativa do potencial eólico de micro e minigeração aplicado a um município de clima \\ subtropical da América do Sul \\ Método de estimación del potencial eólico de la micro y minigeneración aplicado a un municipio de \\ clima subtropical en Sudamérica
}

Received: 08/30/2021 | Reviewed: 09/09/2021 | Accept: 09/13/2021 | Published: 09/14/2021

\author{
Ricardo Guicho \\ ORCID: https://orcid.org/0000-0002-5984-0800 \\ Western Paraná State University, Brazil \\ E-mail: ricardoguicho@gmail.com \\ José Hilário Delconte Ferreira \\ ORCID: https://orcid.org/0000-0002-7116-2600 \\ Federal Technological University of Paraná, Brazil \\ E-mail: jhdferreira@gmail.com \\ Gabriela Medeiros \\ ORCID: https://orcid.org/0000-0002-5444-3064 \\ Western Paraná State University, Brazil \\ E-mail: gabsmedeiros@gmail.com \\ Jair Antônio Cruz Siqueira \\ ORCID: https://orcid.org/0000-0002-8140-444X \\ Western Paraná State University, Brazil \\ E-mail: jair.siqueira@unioeste.br \\ Samuel Nelson Melegari de Souza \\ ORCID: https://orcid.org/0000-0002-3581-902X \\ Western Paraná State University, Brazil \\ E-mail: Samuel.Souza@unioeste.br \\ Maritane Prior \\ ORCID: https://orcid.org/0000-0002-3232-1533 \\ Western Paraná State University, Brazil \\ E-mail: maritane.prior@unioeste.br
}

\begin{abstract}
The search for renewable resources has become necessary for sustainable development. Wind energy is a clean energy source and of global importance, but most studies refer to high altitude and are carried out by researchers in developed countries. In this work, the objective was to evaluate the potential of micro and mini-generation (low heights) wind power in Cascavel-PR, a city located in southern Brazil, as an example of the application of the proposed methodology. For this purpose, wind speed and direction data were used, with a historical series of 21 years (1997-2017). The land use and occupation were performed in a semi-automatic way using Sentinel-2 satellite images. To generate the maps, an algorithm was created in Spring software, which correlated the land use and land cover information, the wind speed kriging and the formula coefficient values according to the identified obstacles. With this it was possible to conclude that regarding the period, spring is considered the season of the year with the greatest energy potential, where the highest averages for speed and power were estimated. It was also noted that the 40 -meter-high range has the greatest potential and that the prevailing winds come from the northeast.
\end{abstract}

Keywords: Wind energy potential; Mapping; Low heights; QGis; Different heights.

\section{Resumo}

A busca por fontes renováveis tornou-se necessária para um desenvolvimento sustentável. A energia eólica é uma fonte de energia limpa e de importância global, porém a maioria dos estudos são referentes à grandes alturas e realizadas por pesquisadores de países desenvolvidos. Neste trabalho, o objetivo foi avaliar o potencial eólico de micro e minigeração (baixas alturas) de Cascavel-PR, município localizado no sul do Brasil, como um exemplo da aplicação da metodologia proposta. Para tanto foram utilizados dados de velocidade e direção do vento, com série histórica de 21 anos (19972017). O uso e ocupação do solo foi realizado de forma semiautomática utilizando imagem do satélite Sentinel-2. Para a geração dos mapas, foi criado um algoritmo no software Spring, que correlacionou as informações de uso e ocupação do solo, a krigagem da velocidade do vento e os valores de coeficiente da fórmula de acordo com os obstáculos 
identificados. Com isso foi possível concluir que quanto ao período, a primavera é considerada a estação do ano de maior potencial energético, onde foram estimadas as maiores médias de velocidade e potência. Constatou-se também, a faixa de 40 metros de altura com o maior potencial e que os ventos predominantes são provindos de nordeste.

Palavras-chave: Potencial de energia eólica; Mapeamento; Baixas alturas; QGis; Diferentes alturas.

\section{Resumen}

La búsqueda de fuentes renovables se ha hecho necesaria para el desarrollo sostenible. La energía eólica es una fuente de energía limpia y de importancia mundial, pero la mayoría de los estudios están relacionados con las alturas y son realizados por investigadores de países desarrollados. En este trabajo, el objetivo fue evaluar el potencial eólico de la micro y minigeneración (bajas alturas) de Cascavel-PR, un municipio situado en el sur de Brasil, como ejemplo de la aplicación de la metodología propuesta. Para ello se han utilizado datos de velocidad y dirección del viento, con una serie histórica de 21 años (1997-2017). El uso y la ocupación del suelo se realizaron de forma semiautomática utilizando imágenes del satélite Sentinel-2. Para generar los mapas, se creó un algoritmo en el software Spring, que correlacionaba la información sobre el uso y la cobertura del suelo, el kriging de la velocidad del viento y los valores del coeficiente de la fórmula según los obstáculos identificados. Con esto se pudo concluir que en lo que respecta al período, la primavera es considerada la estación del año con mayor potencial energético, donde se estimaron los mayores promedios de velocidad y potencia. También se comprobó que el rango de 40 metros de altura tiene el mayor potencial y que los vientos predominantes provienen del noreste.

Palabras clave: Potencial de energía eólica; Mapa; Alturas bajas; QGis; Distintas alturas.

\section{Introduction}

One of the general purposes of the world energy transition is to decarbonize the energy sector. This action requires developing energy generation by using renewable sources for their efficient and sustainable use (Drechsler et al., 2017). Among the countries with high carbon emissions, China and the United States represent $45.6 \%$ of the entire world emissions (Clarke et al., 2009). Thus, the efforts to mitigating carbon emissions are globally essential, to reduce global climate change.

Each country has an environmental characteristic that favors its transition to a more sustainable source. In Brazil, the main source of generation is hydroelectric power, which, according to the National Energy Balance (BEN) (MME, 2018), accounted for $65.2 \%$ of all power generation in 2017 . However, the large share of this source in the electricity matrix puts the security of the system's supply at risk due to the occurrence of droughts, since the scarcity of rain strongly reflects on the ability to generate electricity (Araújo et al., 2021).

Traditionally, the north east region of Brazil is characterized by water shortages, but this deficiency has also started to affect the south east region in recent years, which since 2013 has had the levels of its reservoirs reduced (Almeida \& Benassi, 2015). The water crisis interferes, in this case, not only with the regional sphere but also with the national sphere. However, distributed micro and minigeneration are necessary to consolidate and expand decentralization, assisting in the branching of electricity generation (Chagas et al., 2020), and supplying needs such as excess peak demand, blackout coverage, and the improvement of the qualitative conditions of supply in regions with service deficits (Ramachandra et al., 2014).

To minimize the barriers for the connection of small generating plants to the distribution grid in Brazil, the National Agency of Electric Energy (ANEEL) published the Normative Resolution No. 482/2012, modified by 687/2015. It deals with the production of electricity from small generating plants that use renewable sources (hydraulic, solar, wind, biomass, or qualified cogeneration) connected to the distribution grid through consumer unit facilities (Resolução Normativa $N^{\circ} 687$ de 2015 Da ANEEL, 2015).

As provided in this normative, the distributed micro and minigeneration in Brazil, unlike the global trend that classifies small powers according to dimensional aspects, has the nominal power as its classification basis (Araújo et al., 2021). Microgeneration corresponds to up to 75 kilowatts $(\mathrm{kW})$ and minigeneration fits between 75 kilowatts $(\mathrm{kW})$ to 5 megawatts (MW) of power generation.

Among the renewable sources cited by the normative, the use of wind energy technologies has stood out in recent years.

Its global installed capacity has increased from $94 \mathrm{GW}$ in 2007 to $650 \mathrm{GW}$ in 2019, placing Brazil in $7^{\text {th }}$ position in the ranking 
of total installed capacity (REN21, 2019). In the ranking that accounts for newly installed capacity, Brazil appears in $5^{\text {th }}$ position, having installed $1.94 \mathrm{GW}$. In 2018, Brazil moved up one position in this categorization compared to 2017 (ABEolica, 2019 ).

Of the five Brazilian regions, there are two that stand out in terms of their potential for electricity generation from large turbines: the northeast and southern regions. The largest investments of wind farms in the country are installed in these regions, as a result of investment in research conducted by (MME, 2007), which aimed to identify areas with better conditions for exploiting winds at great heights $(50,75$, and $100 \mathrm{~m})$. Thanks to these investments, of all the energy consumed in southern Brazil in September 2018, 13.72\% was generated from wind sources, with a capacity factor of $77.22 \%$ and a average generation of 1,541.53 MW.

These results were possible with fostering renewable energy, where the wind source also stood out in developing countries such as Brazil, India, Turkey, and Mexico, resulting in a significant growth in research, especially over the last decade. Most (about $80 \%$ ) of the articles on wind energy were written by researchers from developed countries such as the United States, England, Germany, as well as China (Vargas et al., 2019).

Large turbines play a significant role and high government incentives in the Brazilian market, have been consolidated into a large-scale exploitation model with a $99.98 \%$ share of the wind market. Characteristics that limit the participation of small turbines, considered embryonic investments, are mainly due to the lack of economic, marketing, and mainly scientific support, factors which are responsible for the high prices of such projects (Araújo et al., 2021; Chagas et al., 2020; Vargas et al., 2019).

Several studies have analyzed the potential of large farms at great heights(e.g., (Jung \& Schindler, 2020),(Lu \& McElroy, 2017)) for their global potential. The Atlas of the Brazilian Wind Potential (MME, 2007) and the New Atlas of the Brazilian Wind Potential (Neiva et al., 2017) are among the productions that have provided important contributions to the knowledge in the deployment of large structures with heights above 50 meters. However, (Cruz, 2015) and (Araújo et al., 2021) clarified that the heights of interest for micro and minigeneration were below 50 meters. Therefore, it is now necessary to conduct research focused on low height turbines, aiming to map the locations in this segment with wind generation potential.

In Brazil, self-sufficiency by distributed generation is a long-term target unlike, Norway's (105.5\%) or Finland's goals to achieve this by 2025 (Ruggiero et al., 2015). Even more so considering the long-term impact of the resumption of investments in renewable energy after COVID-19 (Sampaio \& Batista, 2021) and the consequences of political instability in the country. However, to achieve decentralization as of micro and minigeneration, measures are needed to consolidate and expand the renewable energy market, especially for small wind farms, since their participation in the country is insignificant, despite their great potential (Araújo et al., 2021).

In this sense, the works of (Giannini et al., 2013) and (Pereira et al., 2018) pointed out that the Brazilian potential for small wind turbines is not yet fully known. This is due to the absence of a specific Wind Atlas, the lack of studies that contemplate development strategies for small wind energy considering as many factors as possible that interfere in this potential, since wind resources are uniquely distributed in each region (Garrido-Perez et al., 2020), in addition to roughness and local orography (Emeksiz \& Cetin, 2019).

The use and occupation of the study area should be well detailed when possible, due to the influence of obstacles interfering with the channeling, direction, or blocking of the wind (Byrne et al., 2019). There is a gap in the research regarding this detailing, since research has so far almost exclusively focused on studies of large wind farms, where the influence of land use and occupation influence is smaller compared to low heights (Chagas et al., 2020).

Therefore, considering the scarcity of research on small turbines, especially in developing countries, this work aimed to fill gaps relating to studies that combine kriging with geographic diversity. Considering the need for electricity generation from renewable sources, as well as the global deficiency of studies of this nature, this research proposes a methodology for 
estimating the wind power potential of the micro and minigeneration of energy applied in a subtropical climate municipality in South America.

\section{Material and Methods}

\subsection{Field of Study}

We carried out the studies in Cascavel (Figure 1), located in western Paraná, in southern Brazil. According to the Instituto Paranaense de Desenvolvimento Econômico e Social (Economic and Social Development Institute of Paraná, IPARDES (IPARDES, 2021)), the city is located between the coordinates $24^{\circ} 57^{\prime} 21^{\prime \prime} \mathrm{S}$ and $53^{\circ} 27^{\prime} 19^{\prime \prime} \mathrm{W}$, at an average altitude of 781 meters, covering an area of 2,091,401 $\mathrm{Km}^{2}$.

Figure 1 - Location of the city of Cascavel - PR.
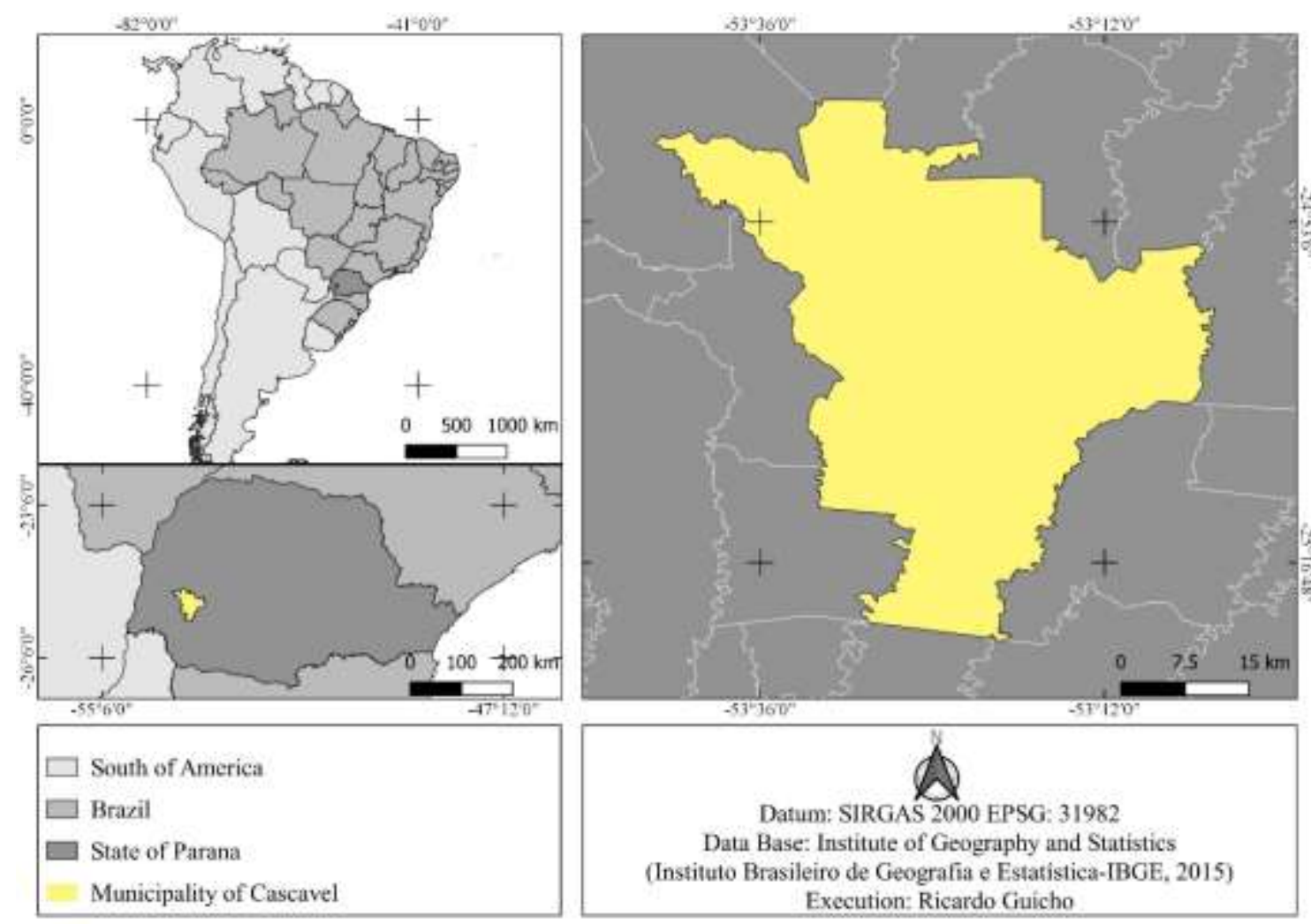

Source: Authors (2021).

According to (Alvares et al., 2013), the city falls under the Cfa climate classification, i.e., having a humid subtropical climate, an average temperature below $18^{\circ} \mathrm{C}$ during the coldest month (humid) and average temperatures above $22^{\circ} \mathrm{C}$ during the warmest month, warm summers, rare incidences of snowfall, heavy rainfall during summers, and no defined dry season.

The annual average temperature varies between 19 and $21^{\circ} \mathrm{C}$, ranging from 14 to $16^{\circ} \mathrm{C}$ during the coldest quarter (June, July, and August), and from 25 to $27{ }^{\circ} \mathrm{C}$ during the warmest quarter (December, January, and February). The annual average rainfall varies between 1,800 and 2,000 mm, ranging from 500 to $600 \mathrm{~mm}$ during the wettest quarter (December, January, and February) and from 250 to $400 \mathrm{~mm}$ during the driest quarter (July, August, and September). The winds predominantly come from the northeast (Nitsche et al., 2019). 


\subsection{Methods}

The proposed methodology is a quantitative analysis that estimates the speed and potential of wind power generation. The results generated, considering the variables analyzed, will be essential in the decision-making process for the use of local wind micro and minigeneration.

The estimation of wind speed and its potential power generation is not a novel concept, however different approaches can be used to understand its behavior. The study by Vargas et al. (2019) (Vargas et al., 2019) sought to evaluate how the analysis of speed/energy for decision-making has evolved over the past 30 years. The authors noted that, despite using various approaches, most articles (54\%) still use statistical models employed for different purposes such as filtering, forecasting, simulation, distribution assembly, modeling, and estimation.

In this work we also used the statistical model built from a historical series of wind speeds collected at meteorological stations, as did (Nunes et al., 2021) who used the wind speed data for application in the Markov chain, or as (Silva et al., 2021) who applied the Multiscale Sample Entropy (MSE) method for Petrolina in northeastern Brazil. The purpose of methodology used in our study was not to perform extrapolated forecasts from a few years as is done in the methodology of measure-correlatepredict (MCP) or the Weibull distribution (Weekes et al., 2015). These methods are usually employed when considering great heights (Carta et al., 2013), with low interference from the soil and its local characteristics.

The goal was to analyze all the data, collected in full, with the advantage of understanding the behavior of the wind at the studied site according to its roughness, land use and orography. The use of these variables correlated in script, with the kriging along the entire municipality, extrapolated from 10 to 20, 30 and 40 meters high. With this information, the local wind speed and potential were estimated more accurately to understand which periods and places in the city had a tendency to present higher or lower potential.

Although kriging has been shown to improve interpolation results (Wang et al., 2021), most studies have not considered local geographic characteristics, since geostatistical methods create an unbiased surface. Its limitation in large areas is related to their spatial extent, whereas for small areas this detailing improves the accuracy of the estimates. Studies that combine kriging with geographic diversity are gaps that this work aims to fill (Friedland et al., 2017).

Due to the size of the historical series, in addition to the realization of land use and correlation processing in the script, significant detailing advantages result from where more comprehensive projects are not characterized, either due to the territorial extent that makes the study impossible, or the generalization of the information. The detailing is important for small turbines due to the influence of obstacles, roughness, and local orography, because of their proximity to the ground. However, the reduced area of influence presents an advantage as it increases the detailing and consequently the accuracy of data, and because a smaller area enables this type of specific research.

\subsubsection{Kriging}

We used a 21-year (1997-2007) series of wind speed and direction data from Cascavel and nine other cities in west Paraná (Brazil), namely, Assis Chateaubriand, Foz do Iguaçu, Guaíra, Palmital, Palotina, Quedas do Iguaçu, Santa Helena, São Miguel do Iguaçu, and Toledo.

The data obtained was used in the kriging, performed in the Surfer 15 (Trial version) (Golden Software, 1999) software, therefore generating a value matrix for wind speed and direction behavior according to the distance between the location points of the weather stations. 


\subsubsection{Classification and roughness of the municipality}

According to SIMEPAR (Paraná Weather System, 2020), the measurement of wind speeds at the stations takes place at an altitude of 10 meters above the ground. We corrected this value for the height of the obstacles surrounding the wind turbine, i.e., buildings or vegetation.

To correct the wind speed, we used the method defended by (Bittencourt \& Cândido, 2006), which applies this formula to estimate the wind speed at the altitudes of building openings. This formula is normally used in architectural designs to estimate the exploitation of natural ventilation in buildings. We chose this method since it considers the behavior of wind coming into contact with the obstacles.

According to (Bittencourt \& Cândido, 2006), the equation (Eq. 1) which corrects the wind speeds at the openings according the roughness factor (Table 1) is the following:

$$
\frac{V}{V m}=k * z^{a}
$$

Where:

V: average wind speed $\left(\mathrm{m} \cdot \mathrm{s}^{-1}\right)$ at the desired altitude;

Vm: average wind speed $\left(\mathrm{m} \cdot \mathrm{s}^{-1}\right)$ at the weather station at a 10-meter height;

$\mathrm{k}$, a: coefficients according to the terrain roughness (Table 1);

z: desired altitude.

Table 1 - Coefficients for determining wind speed for different altitudes and terrains.

\begin{tabular}{ccc}
\hline Location of the building & $\mathbf{k}$ & $\mathbf{a}$ \\
\hline Open plain field & 0,68 & 0,17 \\
Field with some barriers & 0,52 & 0,20 \\
Urban environment & 0,35 & 0,25 \\
Downtown & 0,21 & 0,33 \\
\hline
\end{tabular}

Source: Adapted from (Bittencourt \& Cândido, 2006).

To estimate wind speeds at a new altitude, it is essential to know the height of the obstacles and buildings in the city area. We used an image obtained by the Sentinel 2A satellite, MSI sensor with a 10-meter resolution, from the city of Cascavel - PR, dated from 12/5/2017.

We applied the segmentation tool for supervised classification in the spring (Bhattacharya coefficient) which identified the obstacles. We defined a minimum of 50 samples for each class identified, for training the coefficient. The classes were defined per areas concerned according to (Bittencourt \& Cândido, 2006) which are listed in table 1. The urban area was the only area whose coefficient was carried out manually, divided into "downtown areas", containing the highest buildings, and "residential areas", surrounding the downtown area and covering the rest of the city.

To generate the slope map, we created Numerical Terrain Model (NTM) products, also known as Digital Terrain Models (DTM). The slope information was generated in the spring software and the map was prepared in QGis (QGIS Development Team, 2019). 


\subsubsection{Calculation of power}

To define the available local wind power in Watts (W), (Tolmasquim, 2002) considered the air density ( $\rho$ ), the rotor scanning area (A), and the displacement of an air mass $(\mathrm{m})$ at a speed $\left(\mathrm{v}_{1}\right)$ used the following equation:

$$
\mathrm{P}_{\mathrm{v}}=\frac{1}{2} \cdot \frac{\Delta \mathrm{m}}{\Delta \mathrm{t}} \cdot \mathrm{v}_{1}^{2}
$$

Where $t$ represents the time. Therefore, the flow of mass going through the rotor blades is given by:

$$
\begin{array}{ll}
\frac{\Delta \mathrm{m}}{\Delta \mathrm{t}}=\rho . \mathrm{A} \cdot \mathrm{v}_{1} & \text { Eq. (3) }
\end{array}
$$

Eq. (3) replaces Eq. (2), and the available wind mechanical power varies with the cube of the speed and is given by:

$$
\mathrm{P}_{\mathrm{v}}=\frac{1}{2} \cdot \rho \cdot \mathrm{A} \cdot \mathrm{v}_{1}^{3} \quad \text { Eq. (4) }
$$

Where:

$\mathrm{P}_{\mathrm{v}}$ : Average wind speed in Watts $(\mathrm{W})$;

$\rho$ : Dry air density $=1.225 \mathrm{~kg} / \mathrm{m}^{3}$;

A: Rotor scanning area $\left(\mathrm{m}^{2}\right)$;

v1: Average wind speed $\left(\mathrm{m} \cdot \mathrm{s}^{-1}\right)$.

The choice of wind turbine should consider the information analyzed, i.e., the general configuration of the wind system, the type of application, and the power expected. In this case, we used the Silent-X wind turbine with a rotor area of $1.07 \mathrm{~m}^{2}$.

It is important to highlight that this work did not carry out a technical potential analysis, which considers technical thresholds such as the effectiveness of the equipment. Here, the calculations aim to determine the theoretical potential, i.e., the maximum generation that can be produced by a source considering the physical parameters, and which represents the maximum threshold to be produced (Wohlfarth et al., 2020).

\subsubsection{Algorithm}

With the completion of the correlation between the data obtained, we prepared an algorithm (Appendix A) in the Legal (Special Language for Algebraic Geoprocessing) software in Spring 5.3. This was essential for linking the classification made with the terrain roughness factor and the equation. This data crossing generated thematic maps of the city of Cascavel - PR, separating it into classes differentiated either by the estimated average and maximum wind speeds, or the different generation ranges, prepared in the QGis 2.14 software (QGIS Development Team, 2019). The color classes used in the maps were determined according to the Color Brewer website (Brewer \& Harrower, 2020), to ensure the inclusion of colorblind people.

\subsubsection{Land evidence}

We conducted a sampling selection of each class by acquiring its coordinates and, on-site, we recorded such obstacles through photographs. We used the "Proportional Stratified Sampling" (PSS) for Eqs. (2) and (3) (Bolfarine \& Bussab, 2005). In this procedure, the sample of size $\mathrm{n}$ was distributed proportionally to the size of the strati, i.e.:

$$
\frac{n_{1}}{n}=\frac{N_{1}}{N}, \quad \frac{n_{2}}{n}=\frac{N_{2}}{N},(\ldots), \quad \frac{n_{k}}{n}=\frac{N_{k}}{N}
$$

Therefore, we had: 


$$
n_{1}=\frac{n N_{1}}{N}, n_{2}=\frac{n N_{2}}{N},(\ldots), \quad n_{k}=\frac{n N_{k}}{N}
$$

This technique participates in the stratified sampling, where the population of $\mathrm{N}$ units is primarily divided into subpopulations of N1, N2... Nk units. These populations do not overlap and cover together the whole population so that:

$$
\mathrm{N} 1+\mathrm{N} 2+(\ldots)+\mathrm{Nk}=\mathrm{N}
$$

These subpopulations are strati. Stratification can increase the accuracy of the estimates of characteristics of populations (Cochran, 1965).

Therefore, the number of samples was proportional to the area of each class, i.e., for classes with the larger territory, the number of samples was bigger, when compared with classes of shorter extensions. We obtained 34 photographs for each planting area, 13 for the forest area, one for the residential area, one for the downtown area, and one for the water area.

With the number of photos defined for each class, we chose the points at random with the Google Earth software. We considered determining points that covered the entire territory of the city, thereby making the sampling more representative.

\subsubsection{Wind direction chart}

The wind direction analysis used the "Wind Rose Plot for Meteorological Data" WRPLOT View - Freeware, (Lakes Environmental, 2018). The monthly charts generated contained the wind speed and direction, divided into its maximum and average speeds.

\subsubsection{Statistical analysis}

The possible statistical differences of the kriging resulting variables (average power, maximum power, maximum speed, and average speed) between the seasons of the year and the altitudes were evaluated, using a one-way analysis of variance and, when applicable, the Tukey test, considering a significance level of 5\%.

The same variables were also submitted to principal components analysis (PCA) to characterize and compare the altitudes and seasons of the year evaluated (Wiegleb, 1980), and identify the best performance trend.

The analyses were performed using the R computer statistical environment (R CORE TEAM (R Core Team, 2014)) and the vegan package (Oksanen et al., 2015).

\section{Results and Discussion}

\subsection{Knowledge of local variables}

Besides identifying suitable locations, the main factors affecting the analyses and estimates of wind energy development are wind speed and constancy(Archer \& Jacobson, 2005).

To obtain the information of wind speed and constancy, kriging was performed, and the estimates of the average and maximum monthly powers of the study area were calculated, considering the values of wind speed and direction in the adjacent municipalities. This technique ensures a greater reliability of the estimated data (Friedland et al., 2017), since it considers the wind speed gradient between the meteorological stations for each of the evaluated heights.

Since the micro and minigeneration involve wind turbines positioned at a height of less than 50 meters, identifying and classifying the obstacles is a variable for understanding the wind behavior in the municipality. Therefore, a knowledge of the land use of Cascavel-PR (Figure 2) is fundamental. 
Figure 2 - Location of randomly selected points for ground verification of the semi-automatic classification.

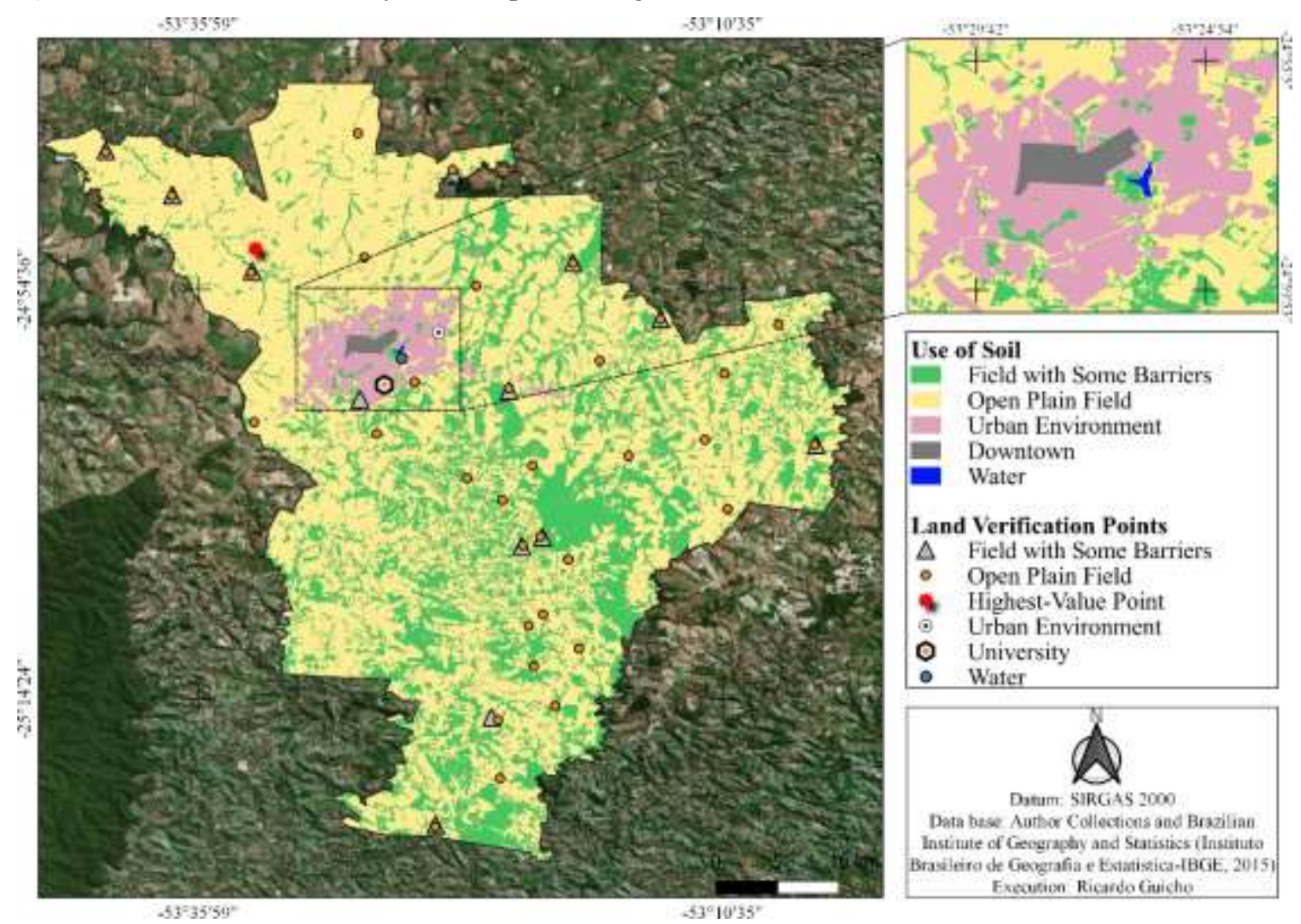

Source: Authors (2021).

The semi-automatic classification performed classified the city of Cascavel into five main land use classes: "Water" $\left(0.54 \mathrm{~km}^{2}\right)$, "Urban Environment" (70.70 km²), "Open and Flat Countryside" (1,458.70 km²), "Countryside with Some Barriers" $\left(552.31 \mathrm{~km}^{2}\right)$, and "City Center" $\left(5.98 \mathrm{~km}^{2}\right)$, totaling 2,088.23 $\mathrm{km}^{2}$.

In addition to land use it was also necessary to know the altitude of the terrain, as it is an important factor in understanding wind behavior, since winds are influenced by topography and surface friction (Byrne et al., 2019; Emeksiz \& Cetin, 2019; Johansson \& Chen, 2003; Whiteman, 2000). For this, we used an elevation model (MDE) to prepare a hypsometric chart along the slope (Figure 3).

In Cascavel, the eastern and mainly the southern regions were the steepest (up to 75\% slope) and the northwestern region was the flattest (from 0 to $20 \%$ slope). However, the hypsometry identified the eastern region as the highest, reaching an altitude of up to $900 \mathrm{~m}$, and containing a "wall" of high hills that extend towards the northwest region (300 m of altitude). 
Figure 3 - 3D images of the city of Cascavel from several perspectives.

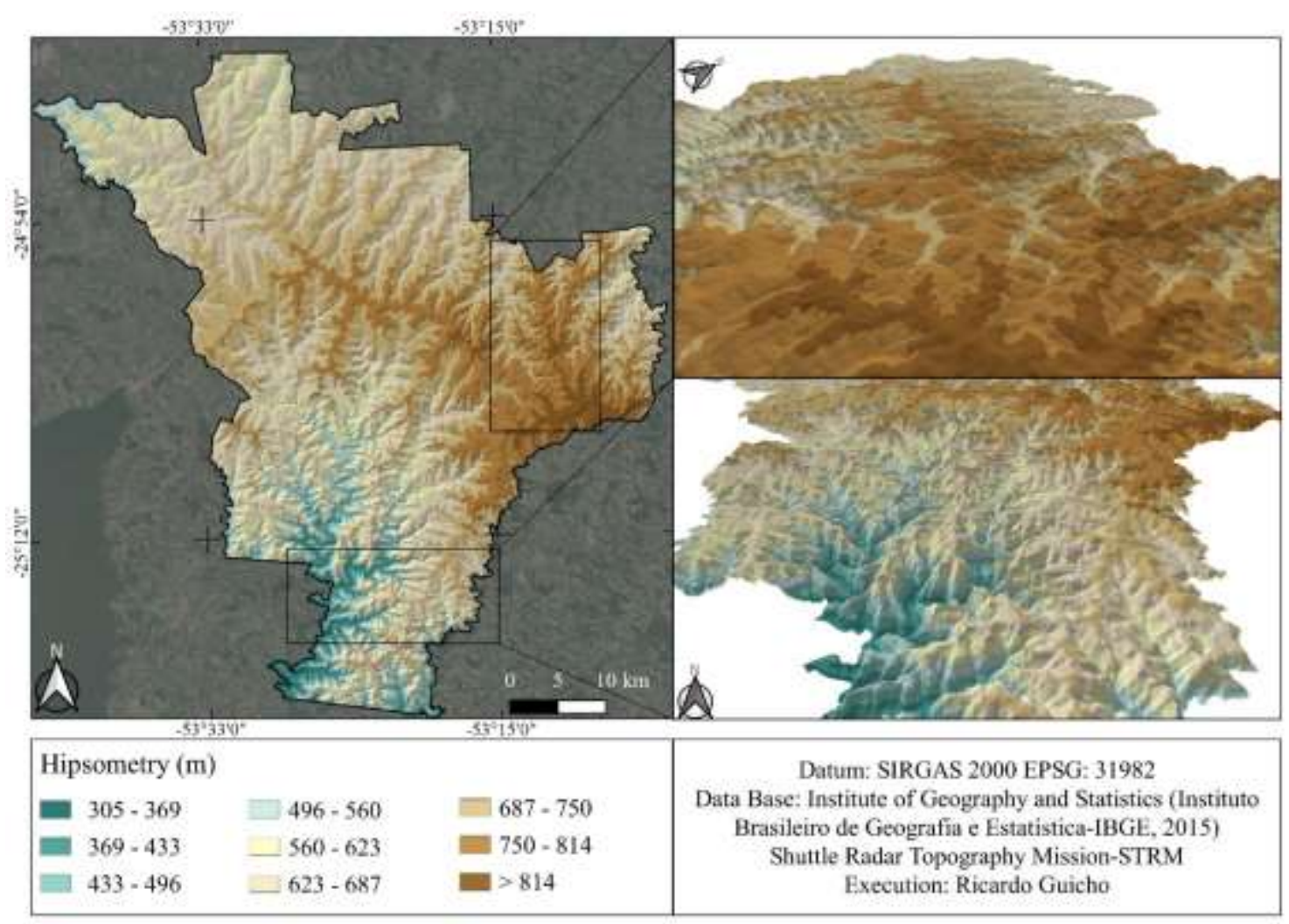

Source: Authors (2021).

Thus, we observed that the altitude in the municipality of Cascavel ranges from $300 \mathrm{~m}$ to 900 meters, with most of its land area occurring between 600 and $900 \mathrm{~m}$. We can emphasize that the highest altitudes occur in the east and extend to the northwest where the topography tends to decrease gradually, suggesting conditions favorable for the high potential for power generation in the region. The 3D images showed that although the southern region of the municipality has a more rugged terrain with steep slopes, classified as "mountainous" to "steep", it is one of the regions with the lowest altitudes.

In the analysis of the relief of the municipality of Cascavel we defined the orographic wall as a decisive factor in the interference of wind direction and speed, since this was a variable that had a clear obstacle effect (Tubelis \& Nascimento, 1980), as was observed in the study by (Sobral et al., 2018) conducted on the coast of Rio de Janeiro.

As a variable of local characteristics, the wind direction is of utmost importance for understanding the behavior of winds in the municipality of Cascavel-PR, so we prepared a wind rose with the monthly averages of the historical series of 21 years. The results were generated in two strands, with the averages of maximum speeds and another with the averages of mean speeds. From them we concluded the direction from the northeast as the predominant one (Supplementary Figures for the wind roses).

\subsection{Mapping the potencies}

The kriging information, correlated by the script created with the relief and land use, allowed the identification of the peaks of maximum power throughout the year that ranged from 488.00 to 2,986.00 Watts according to the maximum velocities. We also observed that the month of October presented the highest maximum power recorded for the estimates (Figure 4), ranging from $1,737.00 \mathrm{~W}$ for 10 meters to $2,986.00 \mathrm{~W}$ for 40 meters. All the largest estimated records were located in the northwestern region of the county. 
Figure 4 - Maximum wind powers, estimated for the month of October referring to 10 (a), 20 (b), 30 (c), and 40 (d) meter heights for the city of Cascavel-PR.

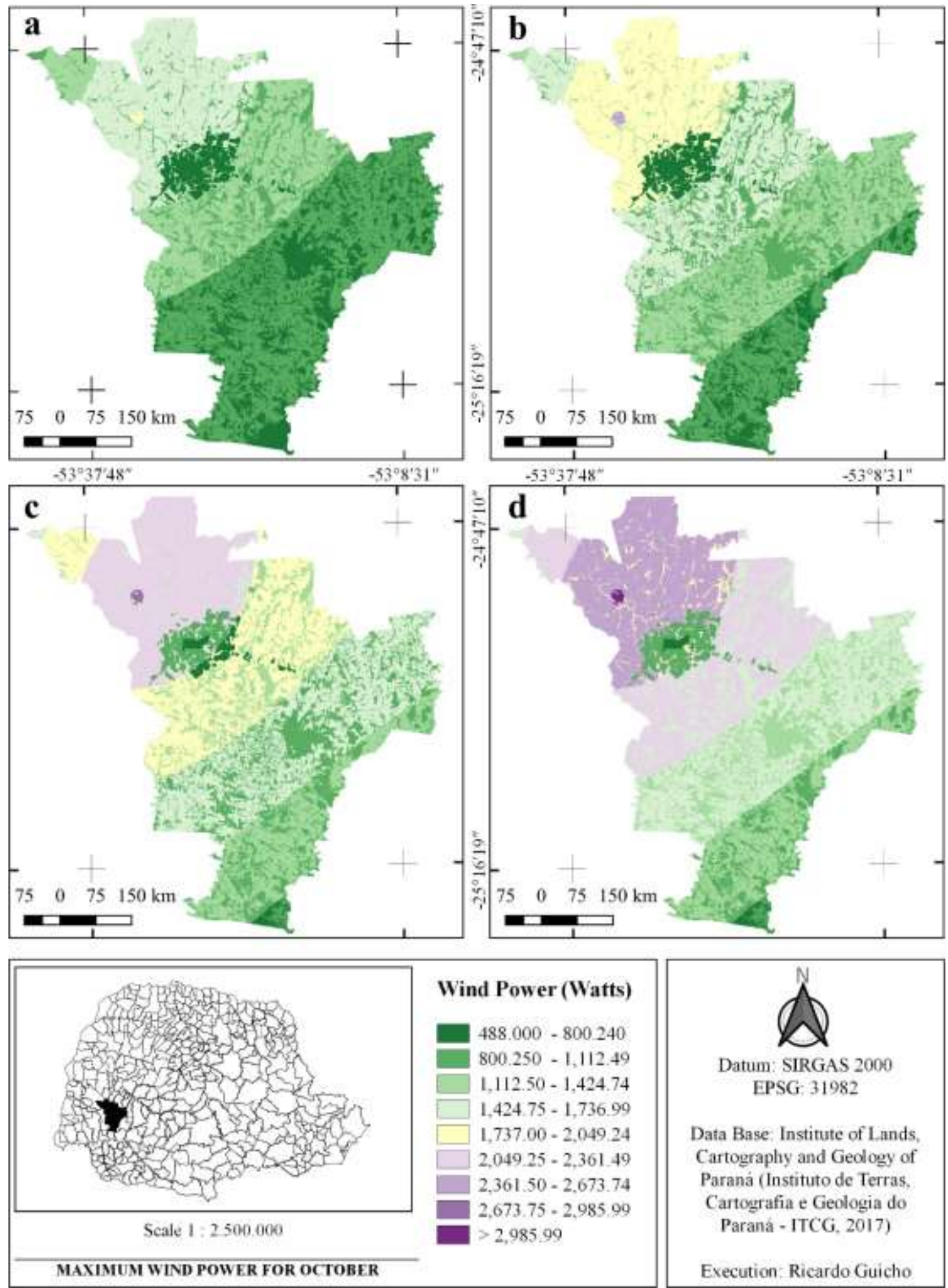

Source: Authors (2021).

In contrast, the maximum peaks identified throughout the month of March ranged from 1,112.49 $\mathrm{W}$ for the 10-meter height, to $1,424.74 \mathrm{~W}$ for the 40-meter height stations (Figure 5). 
Figure 5 - Maximum wind powers, estimated for the month of March referring to 10 (a), 20 (b), 30 (c), and 40 (d) meter heights for the city of Cascavel-PR.
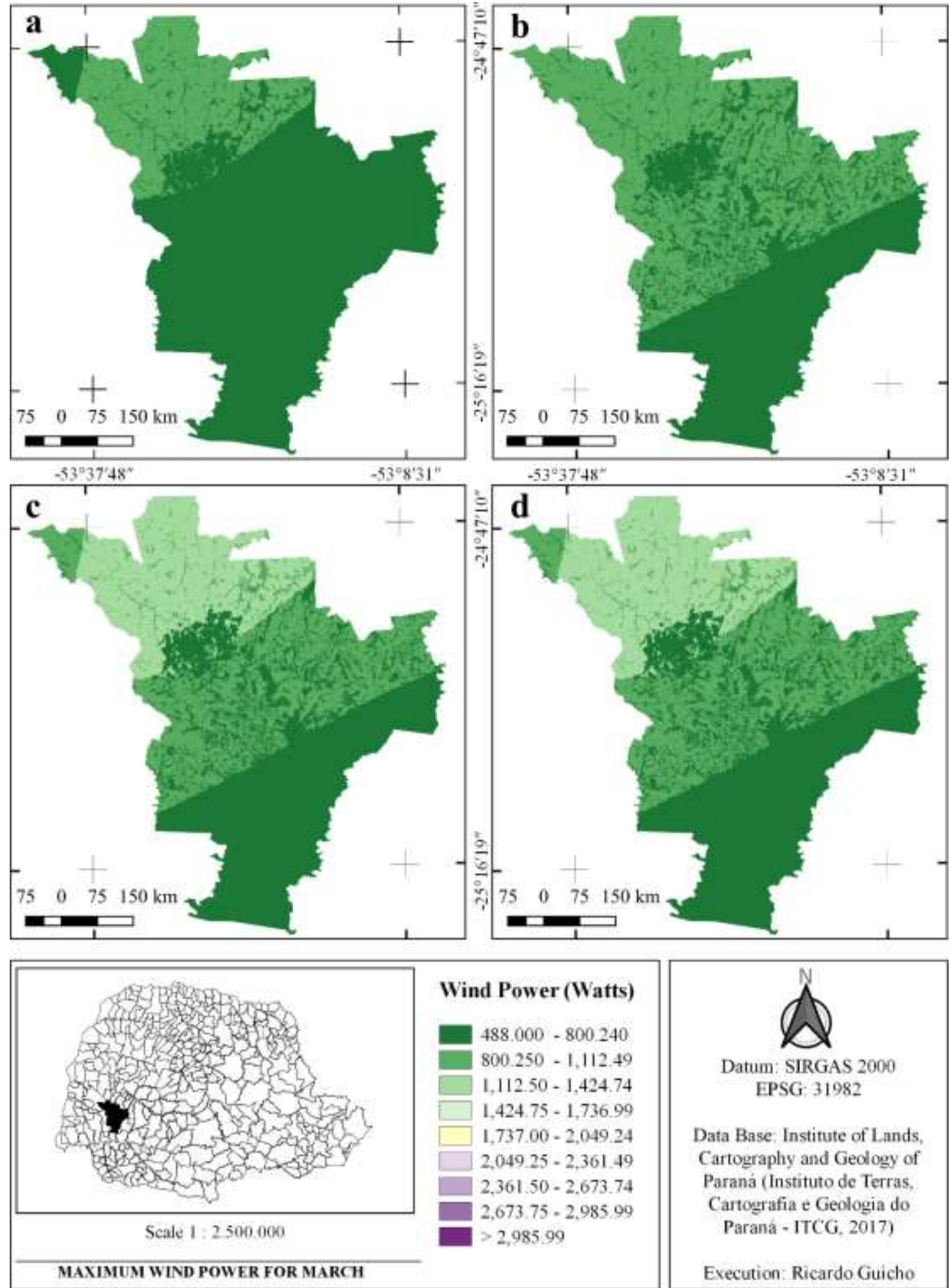

Source: Authors (2021).

Studies such as those by (Chamanehpour et al., 2017) have also addressed the selection of ideal sites for wind power generation using GIS, taking into consideration altitude, relief, land use, and wind speeds to identify the best sites. Unlike our study, the researchers analyzed separately the important variables such as wind speed kriging and later, slope. Land use use were evaluated only for selected sites and not as an interference variable in wind speed and direction. 


\subsection{Statistical Analysis}

For the average power, maximum speed, and average speed data, spring was similar to the winter season. With the exception of the maximum speeds, winter was also statistically similar to the fall and summer seasons (Table 2).

Table 2 - Analysis of the variance of the speed and power variables (maximum and average) in relation to the seasons and the heights.

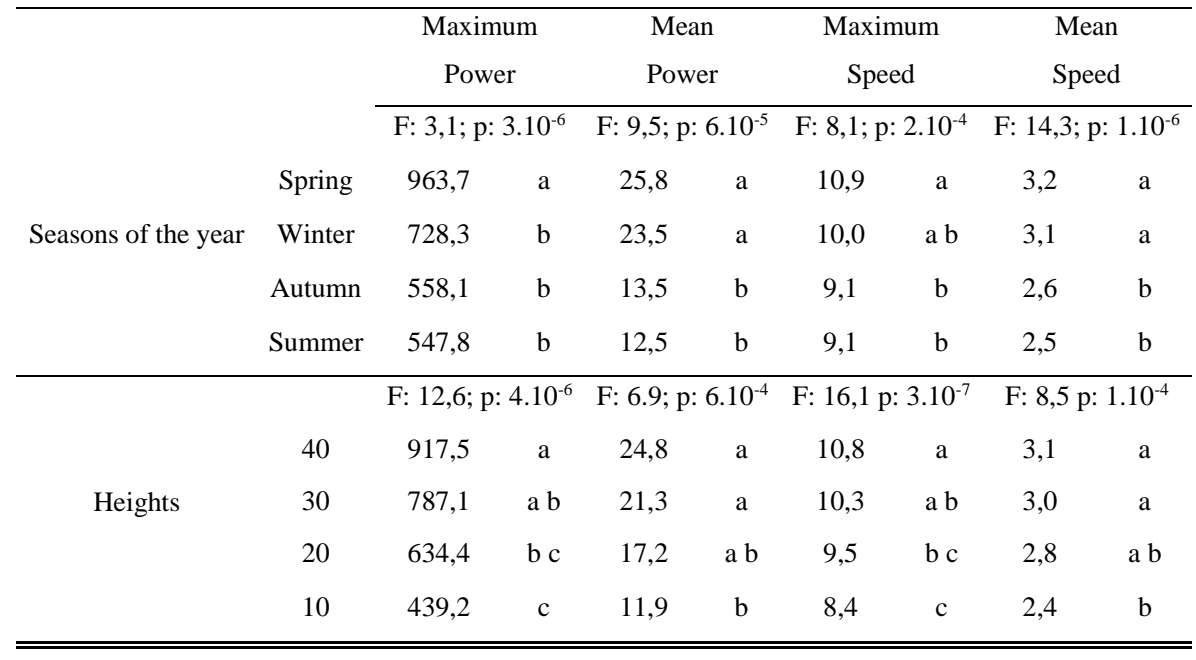

Source: Authors (2021).

Among the evaluated heights, the 30- and 40-meter heights showed more representative averages among the variables, differing in general from the range of 10-20 meters, with an emphasis on the significant difference between 10 and 40 meters. For the mean variables, either power or wind speed, ANOVA identified no significant difference for the height ranges of 20, 30, and 40 meters.

It is important to emphasize that there were no expressive statistical differences between any of the analyzed heights, either for velocity or power variables (maximum or average). However, the maximum speeds and powers at 30 and 40 meters followed the same pattern of comparison which, despite being statistically similar, differed in comparison to the 20-meter height, because the 30 meter height was statistically similar to the 10- and 40- meter heights. It becomes unnecessary to increase 10 meters of rod to raise the wind turbine from 30 to 40 meters, representing a gain that is not statistically significant.

Regarding seasonalities in Paraná, spring is characterized by intense and voluminous rains, resulting from the displacement of cold or warm fronts and events of short duration. Throughout this season, temperatures usually oscillate (Paraná Weather System, 2020). According to the study by (Prates et al., 2000), although the Cascavel region has the highest average wind speed values in western Paraná, it also presents average gusts of higher intensity in October. These are factors that directly influence another aspect cited by the characteristic of the season - the frequency of gusty and gale events - justifying the maximum speeds found in the months referring to spring (Paraná Weather System, 2020). However, gusts are strong winds with a short duration, so they lack the wind property of interest for constant wind generation (Archer \& Jacobson, 2005).

The knowledge of the wind speed is important, but it must always be accompanied by the height of its measurement/estimation and the type of surface on which this was performed (Tubelis \& Nascimento, 1980). Therefore, in Cascavel we observed that the highest power found was $2,986.00 \mathrm{~W}$, at a height of 40 meters, since the surface friction progressively decreases the wind speed as it approaches the surface (Johansson \& Chen, 2003; Whiteman, 2000).

For the ground verification of the wind obstacles identified in the land use classification, we performed a sample selection of each class, acquiring their coordinates, and recorded such obstacles in loco by means of photographs (Appendix 2). 
In one of these locations, we determined a point named the Highest-Value Point (HVP), shown in Figure 3. Since the area covered by the polygon is extensive, we searched satellite images to identify the locations and then photographed them in loco. Near the marked point, still within the polygon of higher velocity, we identified the installation of the SIMEPAR weather radar. The area can also be characterized by an altitude of 716 meters (Figure 2) and the predominance of agricultural use and occupation, according to the thematic map (Figure 3). This region is located northwest of the municipality, at a latitude of approximately $24^{\circ} 52^{\prime} 31^{\prime \prime} \mathrm{N}$ and longitude $53^{\circ} 31^{\prime} 30^{\prime \prime} \mathrm{W}$.

This wall identified in Cascavel may be responsible for directing the wind coming from the northeast, along its length, channeling it to the region of least roughness, since the point of highest power and speed identified is at the end of this path, in the middle of large extensions of agriculture, where wind obstacles are scarce.

The identification of this site can be proven and justified by the characteristics described by (Tubelis \& Nascimento, 1980), which cite principles for the installation of a main weather station, since the highest value point was identified in the vicinity of the meteorological radar of SIMEPAR. The essential local characteristics mainly include free horizons, with high altitudes providing good exposure to the most frequent winds and being away from houses, buildings, rocks, large trees, and other objects that may interfere with the measurements.

Regarding implementation sites, (Archer \& Jacobson, 2005) point outed that developing countries have difficulties in identifying good locations at large scales. However, for micro and mini generation, there are favorable conditions of location in places with the characteristics of Cascavel-PR, such as the extensive areas (69.85\%) of open fields, compared to urban areas (3.67\%). Indeed, the difficulties in finding ideal conditions in urbanized areas are derive from the influence of obstacles (Chagas et al., 2020).

To complement the statistical analysis and show a trend of wind generation for this municipality, we performed PCA which summarized $99.43 \%$ of the total variability of the data sampled in the first two axes (Figure 4). The dispersion of the scores of heights and periods sampled on these axes evidenced a temporal gradient with a clear separation in the diagram of the seasons of the year as well as the heights evaluated.

The first axis of the PCA explained the variability mainly in relation to the maximum power (correlation value: -0.501 ) and average velocity $(-0.501)$ in a negative way, that is, the largest values tended to follow horizontally towards the left. In this axis, the separation was clear between the 40- and 30-meter heights from the others, as it was possible to observe that the left side of the axis contained the representations of the greatest heights, as well as the largest areas of the geometries referring to the winter and spring seasons, which according to the direction, meant a greater maximum power and average speed (Figure 6).

The second axis was positively related to the mean power (0.543), with the highest values occurring northward, and negatively related to the maximum velocity $(-0.517)$, with the highest values occurring southward. This axis differentiated the winter season well from the others since the area of its geometry occurred completely in the northern region (Figure 6). 
Figure 6 - Principal component analysis (PCA) performed to evaluate the sorting trend of the power and speed variables as a function of height and season.

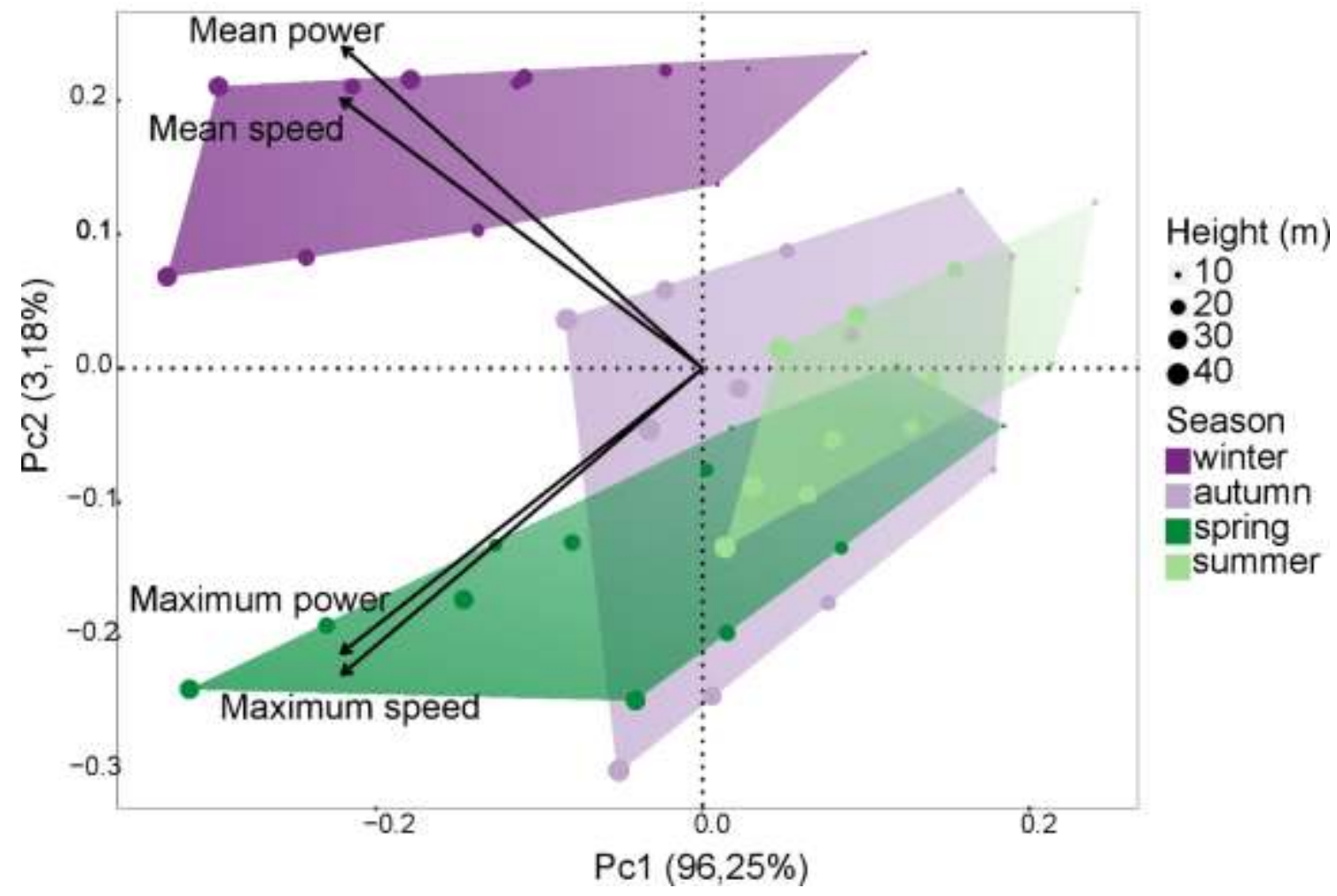

Source: Authors.

According to the results, we identified that the months that make up spring had higher averages for speed and maximum power, being more representative when it came to estimates made at heights of 30 and 40 meters. The months that make up the winter represented higher average values for average speed and power data, unlike spring, with less inconstancy in the winds and a greater representativeness for almost all estimated heights.

Based on the ordination, we selected the month of October, with the most representative score for maximum power (score component 1: $10 \mathrm{~m}: 0.24 ; 20 \mathrm{~m}:-1.70 ; 30 \mathrm{~m}:-3.10 ; 40 \mathrm{~m}:-4.22$ ), referring to spring, and the month of March with the least representativeness (score component 1: $10 \mathrm{~m}: 3.23 ; 20 \mathrm{~m}: 2.08 ; 30 \mathrm{~m}: 1.28 ; 40 \mathrm{~m}: 0.63$ ), referring to summer. Thus, the respective months were chosen to generate thematic charts of maximum estimated power to compare the evaluated heights (Supplementary Material).

We analyzed the PCA results and observed the positioning of the geometries, which are the representations of the seasons. We noticed that spring had all its areas below the second component (indicating higher maximum velocities) and, although the lowest heights were to the right of the axis of the first component, the highest heights were to the left, i.e., they represented the highest heights and therefore resulted in a set of large maximum velocities that tended to have large maximum powers in addition to the average velocities.

Winter and its entire area were located above the second component, and except for the 10-meter height, the other heights were located to the left of the first component. This represents a tendency for high mean power, which is a result of an estimation calculation from high mean velocities in addition to the maximum power. Although the maximum power was representative for both seasons, unlike spring, winter tended to have less inconstancy in its winds.

The "wind constancy" factor could be observed according to the structure and alignment of the points (representing the heights), besides the format of the geometry. For the representation of constant winds in the PCA, the geometry of the station 
must have a regular aspect, with the heights being aligned vertically. A good example of regularity in this work was the geometry of autumn.

Autumn had representation in all 4 quadrants, but its largest area was located on the right side of the first component, alongside summer which had its geometric area completely on the right side. This aspect indicated that for the fall and summer seasons, lower maximum powers and average speeds were found. Still, they had a positive characteristic that manifested as more constant winds, noted by the synchronization of similar symbols that represent the height.

The PCA scores highlighted spring (specifically October as the month of greatest potential) as well as summer (more specifically March as the month of least potential). Thus, it is important to know the wind properties of the season since it is a relevant factor in estimating wind generation.

\section{Conclusions}

This work allowed physical characteristics such as climate, wind speed, wind direction, soil roughness, height, altitude, topography, and infrastructure to be identified as factors that interfere with energy efficiency. This methodology considered each of these variables and correlated them in a script which in turn obtained the maximum power maps presented. The method described was applied to a city with a subtropical climate, located in southern Brazil, with local climatic and geographic characteristics. However, this method can be developed in any region, as long as it considers the typical regional factors.

As a result, the estimates of wind speed (maximum and average) and heights (10, 20, 30, and 40 meters) presented the potential for power generation in Cascavel-PR throughout its territorial extension. We should highlight one region in particular, located in the northwestern region of the city, at a latitude and longitude of approximately $24^{\circ} 52^{\prime} 31^{\prime \prime} \mathrm{S}$ and $53^{\circ} 31^{\prime} 30^{\prime \prime} \mathrm{W}$, identified as the region with the greatest potential.

However, the estimated average speeds varied from 3 to $6 \mathrm{~m} \cdot \mathrm{s}^{-1}$, generating an average power range of 18 to $87 \mathrm{Watts}$. The maximum velocities estimated varied from 9 to $19 \mathrm{~m} \cdot \mathrm{s}^{-1}$, generating a maximum power range of 488 to 2,986 Watts, considering the entire municipality.

The highest values, both for speed and power, were identified in the 40-meter height class. The month of October responsible for the highest estimated value reaching up to $19 \mathrm{~m} \cdot \mathrm{s}^{-1}$ for wind speeds and therefore a generation above $2,986 \mathrm{Watts}$.

In contrast, for the month of March, the maximum levels identified throughout the month ranged from 1,112.49 $\mathrm{W}$ at the height of 10 meters to $1,424.74 \mathrm{~W}$ at the height of 40 meters.

In Cascavel, the eastern and primarily southern regions were the steepest (up to 75\% slope) and the northwest was the flattest (from 0 to $20 \%$ ). However, hypsometry identified the eastern region as the highest, reaching an altitude of up to $900 \mathrm{~m}$, consisting of a "wall" of high hills that extend towards the northwestern region (300 m altitude).

This "wall" could be responsible for channeling the winds from the northeast to the northwest in open fields where the highest speeds and powers occur at the 40-meter height. The best and worst locations for the wind potential were located in the northwestern and southeastern regions, respectively.

Spring stood out presenting significantly higher averages than the other periods for maximum power data. Although it was considered the season of highest power generation, its height located at 40 meters does not statistically justify an investment of 10 meters of rod to raise the wind turbine from 30 to 40 meters, representing a gain that is not statistically expressive.

As limitations of the study, and therefore suggestions for future work, a complementary evaluation with the technical potential should be emphasized, i.e., one that considers the technical limits, such as the efficiency of the chosen equipment.

It is also suggested that the economic viability study, considering scenarios of stability and of energy crisis, as is the current moment in Brazil, pondering the value of the $\mathrm{kWh}$. Besides answering how much energy can be obtained and verifying if the existing transmission network can support this generation. 


\section{Acknowledgements}

The authors wish to thank the Paraná Weather System (SIMEPAR), for the speed and wind direction data of the municipalities, which were essential for the development of this work. We would also like to thank CAPES, because this work was carried out with the support of the Coordenação de Aperfeiçoamento de Pessoal de Nível Superior - Brazil.

\section{References}

ABEolica. (2019). Boletim Anual de Geração Eólica 2019. http://abeeolica.org.br/wp-content/uploads/2020/06/PT_Boletim-Anual-de-Geração-2019.pdf

Almeida, D. L., \& Benassi, R. F. (2015). Crise hídrica e de energia elétrica entre 2014- 2015 na região Sudeste. Revista Hipótese, 1(2), 65-76.

Alvares, C. A., Stape, J. L., Sentelhas, P. C., de Moraes Gonçalves, J. L., \& Sparovek, G. (2013). Köppen’s climate classification map for Brazil. Meteorologische Zeitschrift, 22(6), 711-728. https://doi.org/10.1127/0941-2948/2013/0507

Resolução Normativa ${ }^{\circ} 687$ de 2015 da ANEEL, Pub. L. No. nº 687, Aneel 24 (2015). https://www2.aneel.gov.br/cedoc/ren2015687.pdf

Araújo, F. R. P. de, Pereira, M. G., Freitas, M. A. V., da Silva, N. F., \& Dantas, E. J. de A. (2021). Bigger Is Not Always Better: Review of Small Wind in Brazil. Energies, 14(4), 976. https://doi.org/10.3390/en14040976

Archer, C. L., \& Jacobson, M. Z. (2005). Evaluation of global wind power. Journal of Geophysical Research, 110(D12), D12110. https://doi.org/10.1029/2004JD005462

Bittencourt, L., \& Cândido, C. (2006). Introdução à ventilação natural (2nd ed.). EDUFAL.

Bolfarine, H., \& Bussab, W. O. (2005). Elementos da amostragem. Blücher.

Brewer, C. (The P. S. U., \& Harrower, M. (2020). Color Brewer. https://colorbrewer2.org/\#type=sequential\&scheme=BuGn\&n=3

Byrne, R., Hewitt, N. J., Griffiths, P., \& MacArtain, P. (2019). An assessment of the mesoscale to microscale influences on wind turbine energy performance at a peri-urban coastal location from the Irish wind atlas and onsite LiDAR measurements. Sustainable Energy Technologies and Assessments, 36(September), 100537. https://doi.org/10.1016/j.seta.2019.100537

Carta, J. A., Velázquez, S., \& Cabrera, P. (2013). A review of measure-correlate-predict (MCP) methods used to estimate long-term wind characteristics at a target site. Renewable and Sustainable Energy Reviews, 27, 362-400. https://doi.org/10.1016/j.rser.2013.07.004

Chagas, C. C. M., Pereira, M. G., Rosa, L. P., da Silva, N. F., Freitas, M. A. V., \& Hunt, J. D. (2020). From megawatts to kilowatts: A review of small wind turbine applications, lessons from the US to Brazil. Sustainability (Switzerland), 12(7). https://doi.org/10.3390/su12072760

Chamanehpour, E., Ahmadizadeh, \& Akbarpour. (2017). Site selection of wind power plant using multi-criteria decision-making methods in GIS: A case study. Computational Ecology and Software, 7(2), 49-64. http://www.iaees.org/publications/journals/ces/articles/2017-7(2)/multi-criteria-decision-making-methodsin-GIS.pdf\%0Awww.iaees.org

Clarke, L., Edmonds, J., Krey, V., Richels, R., Rose, S., \& Tavoni, M. (2009). International climate policy architectures: Overview of the EMF 22 International Scenarios. Energy Economics, 31(SUPPL. 2), 64-81. https://doi.org/10.1016/j.eneco.2009.10.013

Cochran, W. G. (1965). Técnicas de Amostragem.

Cruz, D. T. (2015). Micro e minigeração eólica e solar no Brasil: Propostas para desenvolvimento do setor. In Escola Politécnica da Universidade de São Paulo. http://www.teses.usp.br/teses/disponiveis/3/3143/tde-04082015-153708/pt-br.php

Drechsler, M., Egerer, J., Lange, M., Masurowski, F., Meyerhoff, J., \& Oehlmann, M. (2017). Efficient and equitable spatial allocation of renewable power plants at the country scale. Nature Energy, 2(9), 17124. https://doi.org/10.1038/nenergy.2017.124

Emeksiz, C., \& Cetin, T. (2019). In case study: Investigation of tower shadow disturbance and wind shear variations effects on energy production, wind speed and power characteristics. Sustainable Energy Technologies and Assessments, 35(June), 148-159. https://doi.org/10.1016/j.seta.2019.07.004

Friedland, C. J., Joyner, T. A., Massarra, C., Rohli, R. V., Treviño, A. M., Ghosh, S., Huyck, C., \& Weatherhead, M. (2017). Isotropic and anisotropic kriging approaches for interpolating surface-level wind speeds across large, geographically diverse regions. Geomatics, Natural Hazards and Risk, 8(2), 207-224. https://doi.org/10.1080/19475705.2016.1185749

Garrido-Perez, J. M., Ordóñez, C., Barriopedro, D., García-Herrera, R., \& Paredes, D. (2020). Impact of weather regimes on wind power variability in western Europe. Applied Energy, 264(February), 114731. https://doi.org/10.1016/j.apenergy.2020.114731

Giannini, M., Dutra, R. M., \& Guedes, V. G. (2013). Estudo prospectivo do mercado de energia eólica de pequeno porte no Brasil. 21. http://www.cresesb.cepel.br/publicacoes/download/artigo/BrazilWindpower2013-Estudo_Prospectivo_do_Mercado_de_Energia_Eólica_de_Pequeno_Porte_ no_Brasil.pdf

Golden Software. (1999). Surfer (No. 15-Trial Version). www.goldensoftware.com

IPARDES. (2021). Município de cascavel Abril 2021. http://www.ipardes.gov.br/cadernos/MontaCadPdf1.php?Municipio=85800

Johansson, B., \& Chen, D. (2003). The influence of wind and topography on precipitation distribution in Sweden: statistical analysis and modelling. International 
Journal of Climatology, 23(12), 1523-1535. https://doi.org/10.1002/joc.951

Jung, C., \& Schindler, D. (2020). The annual cycle and intra-annual variability of the global wind power distribution estimated by the system of wind speed distributions. Sustainable Energy Technologies and Assessments, 42(October). https://doi.org/10.1016/j.seta.2020.100852

Lakes Environmental. (2018). WRPlot View (8.0.2). https://www.weblakes.com/products/wrplot/index.html

Lu, X., \& McElroy, M. B. (2017). Global Potential for Wind-Generated Electricity. Wind Energy Engineering: A Handbook for Onshore and Offshore Wind Turbines, 106(27), 51-73. https://doi.org/10.1016/B978-0-12-809451-8.00004-7

MME. (2007). Atlas do Potencial Eólico do Paraná. http://www.cresesb.cepel.br/publicacoes/download/atlas_eolico/Atlas_do_Potencial_Eol ico_do_Estado_do_Parana.pdf

MME. (2018). Balanço Energético Nacional 2018. http://www.epe.gov.br/sites-pt/publicacoes-dados-abertos/publicacoes/PublicacoesArquivos/publicacao303/topico-419/BEN2018__Int.pdf

Neiva, A. C. de B., Dutra, R. M., Melo, S. R. F. C. de, Guedes, V. G., Cabrera, A. A. M., Almeida, W. G. de, \& Braz, R. de O. (2017). Atlas do Potencial Eólico Brasileiro: Simulações 2013. Habitat International, 52. http://www.seinfra.ce.gov.br/index.php/downloads/category/6-energia?download=16:p

Nitsche, P. R., Caramori, P. H., Ricce, W. da S., \& Pinto, L. F. D. (2019). Atlas Climático do Estado do Paraná. http://www.iapar.br/arquivos/File/zip_pdf/AtlasClimaticoPR.pdf

Nunes, J. E. de O., Neto, J. V. de S., Silva, M. M. de L., Cordeiro, N. M., Pessoa, R. V. S., Barreto, I. D. de C., Bejan, L. B., \& Stosic, T. (2021). Wind speed analysis using Markov chain. Research, Society and Development, 10(9), 1-9.

Oksanen, J., Blanchett, F. G., \& Kindt, R. et al. (2015). Vegan: community ecology package.

Paraná Weather System. (2020). SIMEPAR. www.simepar.br/prognozweb/simepar/post/14037

Pereira, M. G., Da Silva, N. F., De Melo, S. R. F. C., Freitas, M. A. V., \& Guedes, V. G. (2018). Integrated assessment of energy potential and social aspects: Case study of small wind in the state of Rio Grande do Norte. SBSE 2018 - 7th Brazilian Electrical Systems Symposium, 1-6. https://doi.org/10.1109/SBSE.2018.8395887

Prates, J. E., Zaicovski, M. B., \& K., G. (2000). Variabilidade temporal e espacial do vento médio e de rajada no Paraná. Encyclopedia of Volcanoes., $1995,662$. QGIS Development Team. (2019). QGIS (3.4.4-Madeira). General ublic License (GNU). www.qgis.org/

R Core Team. (2014). R. www.rproject.org

Ramachandra, T. V., Hegde, G., \& Krishnadas, G. (2014). Potential assessment and decentralized applications of wind energy in Uttara Kannada, Karnataka. International Journal of Renewable Energy Research, 4(1), 1-10.

REN21. (2019). Renewables 2019 Global Status Report Collaborative. In Ren21 (Vol. 105, Issue July). http://www.ren21.net/gsr2019/pages/foreword/foreword/

Ruggiero, S., Varho, V., \& Rikkonen, P. (2015). Transition to distributed energy generation in Finland: Prospects and barriers. Energy Policy, 86, $433-443$. https://doi.org/10.1016/j.enpol.2015.07.024

Sampaio, K. R. A., \& Batista, V. (2021). The current scenario of wind energy production in Brazil : A literature review. Research, Society and Development, $10(1), 1-8$.

Silva, G. F. da, Barreto, I. D. de C., \& Stosic, T. (2021). Multiscale entropy analysis of wind speed dynamics in Petrolina, Northeast Brazil. Research, Society and Development, 10(1), 1-9. https://doi.org/10.33448/rsd-v10i1.11460

Sobral, B. S., Oliveira Júnior, J. F. de, Gois, G. de, Terassi, P. M. de B., \& Pereira, C. R. (2018). Regime de Vento na Serra do Mar - Rio de Janeiro, Brasil. Revista Brasileira de Meteorologia, 33(3), 441-451. https://doi.org/10.1590/0102-7786333004

Tolmasquim, M. T. (2002). Fontes Renováveis de Energia no Brasil. Editora Interciência Ltda.

Tubelis, A., \& Nascimento, F. J. L. do. (1980). Meteorologia descritiva: fundamentos e aplicações brasileiras. Nobel.

Vargas, S. A., Esteves, G. R. T., Maçaira, P. M., Bastos, B. Q., Cyrino Oliveira, F. L., \& Souza, R. C. (2019). Wind power generation: A review and a research agenda. Journal of Cleaner Production, 218, 850-870. https://doi.org/10.1016/j.jclepro.2019.02.015

Wang, Z., Bui, Q., Zhang, B., Nawarathna, C. L. K., \& Mombeuil, C. (2021). The nexus between renewable energy consumption and human development in BRICS countries: The moderating role of public debt. Renewable Energy, 165, 381-390. https://doi.org/10.1016/j.renene.2020.10.144

Weekes, S. M., Tomlin, A. S., Vosper, S. B., Skea, A. K., Gallani, M. L., \& Standen, J. J. (2015). Long-term wind resource assessment for small and mediumscale turbines using operational forecast data and measure-correlate-predict. Renewable Energy, 81, 760-769. https://doi.org/10.1016/j.renene.2015.03.066

Whiteman, D. C. (2000). Mountain Meteorology: Fundamentals and Applications. Oxford University Press.

Wiegleb, G. (1980). Some applications of principal components analysis in vegetation: Ecological research of aquatic communities. Vegetatio, 42(1-3), 67-73. https://doi.org/10.1007/BF00048872

Wohlfarth, K., Klobasa, M., \& Gutknecht, R. (2020). Demand response in the service sector - Theoretical, technical and practical potentials. Applied Energy, 258(October 2019), 114089. https://doi.org/10.1016/j.apenergy.2019.114089 